\title{
Assessment of Biochemical Indices in Haemolytic Crisis with Special Reference to Sickle Cell Anaemia
}

\author{
Prashant Nigam ${ }^{1}$, Rakesh Nahrel ${ }^{2}$, Amit Thakur ${ }^{3}$ \\ ${ }^{1}$ Department of Biochemistry, Chhattisgarh Institute of Medical Sciences, Bilaspur, Chhattisgarh, India. ${ }^{2}$ Department of \\ Paediatrics, Chhattisgarh Institute of Medical Sciences, Bilaspur, Chhattisgarh, India. ${ }^{3}$ Department of Medicine, \\ Chhattisgarh Institute of Medical Sciences, Bilaspur, Chhattisgarh, India.
}

\section{ABSTRACT}

\section{BACKGROUND}

Sickle cell anaemia (SCD) is a global genetic disease. Potential changes in multiple biochemical indices are also often a major factor behind the varied clinical presentation of SCD. Various studies were conducted to establish the relation between SCD associated manifestations with biochemical imbalance in sickle cell patients but still picture is opaque. In the present study we tried to enhance the data for better understanding of role of biochemical indices in SCD.

\section{METHODS}

The present independent case control study was done in the Department of Biochemistry, Chhattisgarh Institute of Medical Sciences, Bilaspur. It comprised of two different groups consisting 80 sickle cell patients with hyper haemolytic crisis, including 80 age and sex matched control subject. In the present study we measured various biochemical indices including ALT, AST, ALP, GGT, total protein, albumin, bilirubin (total, direct \& indirect), urea \& creatinine. Statistical analysis was done by using t test.

\section{RESULTS}

We found statistically significant differences in mean level of ALT (20.66 \pm 5.31 , $151.78 \pm 30.36,<0.001)$, AST $(21.56 \pm 5.12,65.76 \pm 5.1,<0.001)$, ALP $(77.00 \pm$ $16.36,365.72 \pm 8.3,<0.001)$, GGT $(23.00 \pm 6.67,168.00 \pm 4.39,<0.001)$, total protein $(7.00 \pm 0.35,8.43 \pm 0.39,<0.001)$, albumin $(4.00 \pm 0.24,3.85 \pm 0.35,<0.05)$, T. Bilirubin $(1.19 \pm 0.17,18.95 \pm 3.69,<0.001)$, D. Bilirubin $(0.59 \pm 0.15,8.81 \pm 1.89$, $<0.001)$, I. Bilirubin $(0.49 \pm 0.20,10.14 \pm 2.54,<0.001)$ when compared with control. Renal indices like urea $(30.82 \pm 4.75,28.43 \pm 9.33$, > 0.05), and creatinine $(0.98 \pm 0.18,0.95 \pm 0.27,>0.05)$ have no significant differences.

\section{CONCLUSIONS}

In the present study we observed interrelation of various biochemical indices with hyper haemolytic crisis. Further studies are required to strengthen the above observations.

\section{KEY WORDS}

Sickle Cell Anaemia, Hyper Haemolytic Crisis, Biochemical Indices
Corresponding Author: Dr. Prashant Nigam, Associate Professor, Department of Biochemistry, Chhattisgarh Institute of Medical Sciences, Bilaspur, Chhattisgarh, India. E-mail: nigam.prashant866@gmail.com

DOI: $10.14260 /$ jemds $/ 2022 / 4$

How to Cite This Article:

Nigam P, Nahrel R, Thakur A. Assessment of biochemical indices in haemolytic crisis with special reference to sickle cell anaemia. J Evolution Med Dent Sci 2022;11(01):17-20, 10.14260/jemds/2022/4

Submission 22-12-2021,

Peer Review 03-01-2022,

Acceptance 06-01-2022,

Published 11-01-2022.

Copyright (C) 2022 Prashant Nigam et al. This is an open access article distributed under Creative Commons Attribution License [Attribution 4.0 International (CC $B Y 4.0)]$ 


\section{BACKGROUND}

Sickle cell is the most common single gene mutation disease worldwide mainly present in Africa, Mediterranean countries, Middle East and parts of South American countries and India. ${ }^{1}$ SCD is still a challenging task for the doctors and scientists of the world. Treatment of the disease is available on the basis of symptoms, but it is also not effective in many circumstances. If we look about the history of sickle cell, we find that it was first described by Chicago based physician Dr. Herrick in the year $1910 .^{2}$ Since then various information are available regarding SCD.

In SCD, mainly four crises' conditions are found. ${ }^{3,4,5}$ Vasoocclusive crisis is the most common clinical manifestation with varying frequency in different individuals mainly due to tissue hypoxia leading to tissue death and accompanying pain. ${ }^{6}$

Aplastic crisis in sickle cell anaemia is another crisis, resulting in an acute, sever drop in haemoglobin levels and usually associated with infections. ${ }^{7}$ Sequestration crisis is characterized by sudden, massive pooling of red cells, especially in the spleen, which may result in hypovolemic shock and cardiovascular collapse. ${ }^{8}$ Haemolysis of red blood cells mainly occurs in haemolytic crisis. Hyper haemolytic crises, in SCD, are more common in places where there is a history of frequent malaria infection. ${ }^{9}$

The clinical spectrum of SCD ranges from mild to severe liver function alteration. SCD includes multiple organ dysfunctions especially liver ranges from mild to severe alterations. In SCD bone deformities are commonly seen but the pathogenesis is still unclear. Persons with homozygous or heterozygous sickle cell conditions may have various renal abnormalities. ${ }^{10}$ In the present study we tried to enhance the data for better understanding of role of biochemical indices in SCD.

\section{METHODS}

The present independent case control study was carried out in the Department of Biochemistry, Chhattisgarh Institute of Medical Sciences, Bilaspur, CG. Ethical clearance from Institutional Ethics Committee was taken prior to the start of study. As per institutional guidelines informed consent were taken from all the participants.

Consent was obtained from guardian if the participant is minor. The study includes 80 subjects with homozygous sickle cell patients (HbSS) and 80 age matched healthy controls (HbAA). The sample size for case and control were determined by using EPI Info software. Hyper haemolytic crisis was defined on the basis of significant changes in haemoglobin concentration, hyper bilirubinaemia, reticulocytosis, polychromasia, and increased urobilinogen. SCD patients who were confirmed electrophoretically, aged between 2 to 20 years of both genders were included in study.

Patients with any other crises, having history of blood transfusion within three months, steroidal or antiinflammatory drug therapy, paediatric patients with hypersplenism were excluded. A blood sample was taken as per standard protocol and immediately processed to separate the serum. All biochemical indices investigations were done by fully automatic biochemical analyser.

\section{Statistical Analysis}

All numerical values were entered in Microsoft Excel 2000. Data analysis were performed by SPSS software 22.0. Continuous data were summarized as mean+/-SD (standard deviation). All tests were applied after ascertaining normality by Shapiro-Wilk test after that independent sample $t$ test was used for comparison between case and control with respect to all parameters. A two tailed $\mathrm{P}$ value less than $0.05(\mathrm{P}<0.05)$ was considered statistically significant.

\section{RESULTS}

\begin{tabular}{|c|c|c|c|c|}
\hline Sl. No. & Parameters & $\begin{array}{c}\text { Control } \\
\text { Mean } \pm \text { SD }\end{array}$ & $\begin{array}{c}\text { Haemolytic Crisis } \\
\text { Mean } \pm \text { SD }\end{array}$ & $\begin{array}{c}\text { P } \\
\text { Value }\end{array}$ \\
\hline 1. & ALT (IU/L) & $20.66 \pm 5.31$ & $151.78 \pm 30.36$ & $<0.001$ \\
\hline 2. & $\operatorname{AST}(\mathrm{IU} / \mathrm{L})$ & $21.56 \pm 5.12$ & $65.76 \pm 5.1$ & $<0.001$ \\
\hline 3. & ALP (IU/L) & $77.00 \pm 16.36$ & $365.72 \pm 8.3$ & $<0.001$ \\
\hline 4. & GGT (IU/L) & $23.00 \pm 6.67$ & $168.00 \pm 4.39$ & $<0.001$ \\
\hline 5. & Total protein (g/dl) & $7.00 \pm 0.35$ & $8.43 \pm 0.39$ & $<0.001$ \\
\hline 6. & Albumin (g/dl) & $4.00 \pm 0.24$ & $3.85 \pm 0.35$ & $<0.05$ \\
\hline 7. & Total bilirubin (mg/dl) & $1.19 \pm 0.17$ & $18.95 \pm 3.69$ & $<0.001$ \\
\hline 8. & Direct bilirubin (mg/dl) & $0.59 \pm 0.15$ & $8.81 \pm 1.89$ & $<0.001$ \\
\hline 9. & Indirect bilirubin $(\mathrm{mg} / \mathrm{dl})$ & $0.49 \pm 0.20$ & $10.14 \pm 2.54$ & $<0.001$ \\
\hline 10. & Urea $(\mathrm{mg} / \mathrm{dl})$ & $30.82 \pm 4.75$ & $28.43 \pm 9.33$ & $>0.05$ \\
\hline 11. & Creatinine (mg/dl) & $0.98 \pm 0.18$ & $0.95 \pm 0.27$ & $>0.05$ \\
\hline
\end{tabular}

In the present study we assessed the liver function by measuring various biochemical indices like ALT, AST, ALP, GGT, total protein, albumin, bilirubin and renal function by measuring urea and creatinine. Values were expressed in mean \pm SD. We found significant differences in all parameters except urea and creatinine when compared to hyper haemolytic crises group to age and sex matched normal control group. In case of albumin, we found less significant status during comparison of both the groups.

\section{DISCUSSION}

The presentation of haemolytic anaemia in SCD is one of the most important and noticeable condition among all the haemoglobinopathies. In SCD, ischemic tissue injury is found mainly due to vaso-occlusion and susceptibility to infections in patients. ${ }^{11}$ Only few effective therapeutics are available to treat the various clinical conditions of SCD. Haemoglobin is one of the important protein present in RBC. It consists of four globin chain. Each chain is folded around the iron containing heme molecule. Haemoglobin is involved in the transportation of oxygen and CO2. In adulthood the predominant haemoglobin in $\mathrm{HbA}( \pm 97 \%)$ which consists of two $\alpha$ and two $\beta$ globin chains $(\alpha 2 \beta 2)$. At the time of intrauterine development, various globin chains like $\alpha, \beta, \gamma, \delta$, $\varepsilon$, are synthesized. ${ }^{12} \mathrm{~A}$ single point mutation in the $6^{\text {th }}$ codon leads to substitution of glutamic acid for valine, which results in an abnormal globin: $\beta$ s. This results in the formation of sickle haemoglobin (HbS). During deoxygenation $\beta$ s interact with another adjacent $\beta$ s via hydrophobic interactions. This 
results in polymerization of $\beta \mathrm{s}$ chain ultimately leads to crescent shaped RBC. ${ }^{13}$ The clinical manifestation of sickle cell anaemia in India are less severe than in other countries like Africa and Jamaica. ${ }^{14}$ The clinical features of SCD varies according to the degree of severity of effect on liver which can lead to hyperbilirubinemia, liver failure and clinical crises $^{10}$. The factors like ischemia, iron overload, gallstones and viral hepatitis due to transfusion required in the management of SCD are the aetiological factors responsible for the liver disease. ${ }^{15}$

Aspartate aminotransferase (AST) and alanine aminotransferase (ALT) are the enzymes which are released by liver in abnormal conditions. In SCD related haemolysis AST and ALT level is also raised. The current study found the levels of AST and ALT to be higher in individual with haemolytic crisis in comparison to the control group (ALT $\mathrm{p}<0.001$, AST $\mathrm{p}<0.001)$. This is in concurrence with the study by Johnson et al. ${ }^{16}$ and Nsiah $\mathrm{K}^{17}$ who have reported marked increase of AST and ALT in sickle cell hepatopathy associated with sickle cell crises in SCD. The comparison of ALP level in the hyper haemolytic group with the control group also showed high significance $(p<0.001)$ in the present study. There was a significant increase in the serum levels of ALP, AST and GGT in individuals with sickle cell anaemia with persistent hepatomegaly when compared with those individuals without hepatomegaly $(\mathrm{p}<0.05, \mathrm{p}<0.05$ and $\mathrm{p}<$ 0.01 respectively) in a study by Oparinde DP et al. (2006).18 The SCA individuals with persistent hepatomegaly also had significantly higher final aggregate severity scores and all the index scores. GGT was the only hepatic enzyme that showed positive and highly significant correlation with the clinical severity $(\mathrm{r}=0.46, \mathrm{P}<0.05) .{ }^{18}$ The study by Yahaya et al. ${ }^{19}$ reported that alkaline phosphatase, alanine aminotransferase and aspartate aminotransferase were significantly higher $(\mathrm{P}<0.05)$ whereas total protein and albumin did not show any significant change in the HbSS subjects when compared with the control subjects. The study by Ojuwa et al.20 which included 30 children with sickle cell anaemia also found that the levels of alanine aminotransferase, alkaline phosphatase and bilirubin was significantly higher $(p<0.005)$ while the levels of total protein and albumin showed no significant difference in the subjects during haemolytic crises and after recovery. The level of total protein and albumin in our study was higher than the normal reference range which was statistically significant when hyper haemolytic group was compared with the control group of subjects and therefore, in concurrence with the findings of the above study.

Buchanan et al. ${ }^{21}$ in their study including 6 children with minimal or no symptoms reported only mild elevation in ALT levels with hyperbilirubinemia (up to $57 \mathrm{mg} / \mathrm{dl}$ ) which was predominantly conjugated bilirubin in most subjects. Ebert EC et al.22 also reported an elevation of unconjugated bilirubin and mentioned that the excessive haemolysis of RBC in the subjects with haemolytic crisis has resulted in the higher level of serum bilirubin. The current study has found significant mean difference in serum bilirubin concentration when the group of subjects with haemolytic crises was compared with controls $(\mathrm{p}<0.001)$.

In SCD bone deformities are commonly seen but the pathogenesis is still unclear. ${ }^{10,23}$ The severity of bone damage is represented by level of alkaline phosphate and same can be used as a prognosis marker in management of sickle cell related bone disease. ${ }^{24,25}$ Vit D deficiency, low bone mineral density, osteoporosis and osteomalacia are normally present in SCD patients. Increased level of ALP in sickle cell patients may be due to bone destruction, delayed bone growth and bone-associated vaso-occlusive crisis instead of liver pathology. ${ }^{26}$ The extent and severity of bone damage is represented by increased level of ALP and it can be used as a good marker to assess bone damage as well as prognosis during the management of SCD; In our study we also observed the increased level of ALP in the patients with haemolytic crisis. There was high statistical significance in comparison between both the groups $(\mathrm{P}<0.001)$. This finding is consistent with Isichei UP27 and Brody JI et al. ${ }^{28}$ who have studied the status of ALP in SCD patients and reported bone ALP as a principal but not sole parameter increased during presence of clinical symptom related to bone in SCD. They also reported increased ALP level in asymptomatic subjects. GGT may be used as another important enzyme to assess the liver function in SCD. Oparinde DP et al. reported significant positive correlation $(\mathrm{r}=0.46, \mathrm{P}<0.05)$ between $\mathrm{GGT}$ and severity among the hepatic enzymes in sickle cell patients. In the present study, we have also observed raised level of GGT in Group II (haemolytic crisis) and found it to be statistically significant when compared with normal group. The above observations suggest that ALP and GGT levels can be used as an indicator in SCD to assess the frequency, degree and persistence of tissue injury. ${ }^{27,28}$

Persons with homozygous or heterozygous sickle cell conditions may have various renal abnormalities.10,29,30 Marouf $\mathrm{R}$ et al. ${ }^{30} \mathrm{Al}$ Naama LM et al. ${ }^{31}$ have reported low urea and creatinine in subjects with SCD. In the present study, we found low levels of blood urea $(28.43 \pm 9.33, p>0.05)$ in haemolytic crisis subjects when compared with the control group subjects whereas the creatinine level was not statistically significant $(0.95 \pm 0.27, \mathrm{p}>0.05)$ in comparison among the groups. Therefore, it can be concluded that renal insufficiency is uncommon in SCD subjects in India.

\section{CONCLUSIONS}

In the present study we observed correlation of various biochemical indices associated with liver and its pathophysiology with hyper haemolytic crisis. Although we did not find any correlation between renal parameters and haemolytic crises associated with SCD. ALP and GGT can be used to assess tissue injury in SCD associated haemolytic crises, although further studies are required to confirm the above observations.

Data sharing statement provided by the authors is available with the full text of this article at jemds.com.

Financial or other competing interests: None.

Disclosure forms provided by the authors are available with the full text of this article at jemds.com.

\section{REFERENCES}

[1] Oner C. Beta S haplotypes in various world populations. Human Genetics 1992;89(1):99-104. 
[2] Herrick JB. Peculiar elongated and sickle-shaped red blood corpuscles in a case of severe anaemia. Arch Intern Med 1910;6(5):517-21.

[3] Diggs LW. The crises in sickle cell anaemia. Heamatological studies. Am J Clin Pathol 1956;26(10):1109-18.

[4] Sergeant GR, Serjeant BE. Sickle cell disease. $2^{\text {nd }}$ edn. New York: Oxford Press 1992.

[5] Neonato MG, Guilloud-Bataille M, Beauvais P, et al. Acute clinical events in 299 homozygous sickle cell patients living in France. French study group on sickle cell disease. Eur J Haematol 2000;65(3):155-64.

[6] Jacob E, Beyer JE, Miaskowski C, et al. Are there phases to the vaso-occlusive painful episode in sickle cell disease? J Pain Symptom Manage 2005;29(4):392-400.

[7] Smith-Whitley K, Zhao H, Hodinka RL, et al. Epidemology of human parvovirus B19 in children with sickle cell disease. Blood 2004;103(2):422-7.

[8] Kinney TR, Ware RE, Schultz WH, et al. Long term management of splenic sequestration in children with sickle cell disease. J Pediatr 1990;117(2 Pt 1):194-9.

[9] Okunoghae HO, Nwankwo MU, Offer E. Malaria parasitaemia in febrile children with sickle cell anaemia. J Trop Paediatr 1992;38(2):83-5.

[10] Pandey S, Sharm A, Dahia S, et al. Biochemical indicator of sickle cell disease: preliminary report from India. Indian J Clin Biochem. 2012;27(2):191-5.

[11] Sundd P, Gladwin MT, Novelli EM. Pathophysiology of sickle cell disease. Annu Rev Pathol 2019;14:263-92.

[12] Sankaran VG, Orkin SH. The switch from fetal to adult haemoglobin. Cold Spring Harb Perspect Med 2013;3(1):a011643.

[13] Renaudier P. Sickle cell pathophysiology. Transfus Clin Biol 2014;21(4-5):178-81.

[14] Mohanty D, Mukheriee MB. Sickle cell disease in India. Curr Opin Hepatol 2002:9(2):117-22.

[15] Banerjee S, Owen C, Chopra S. Sickle cell hepatopathy. Hepatology 2001;33(5):1021-8.

[16] Johnson CS, Omata M, Tong MJ, et al. Liver involvement in sickle cell disease. Medicine (Baltimore) 1985;64(5):34956.

[17] Nsiah K, Dzogbefia VP, Ansong D, et al. Pattern of AST and ALT changes in relation to haemolysis in SCD. Clin Med Insight Blood Disord 2011;4:1-9.
[18] Oparinde DP, Oghagbon EK, Okesina AB, et al. Role of hepatic enzymes in the biochemical assessment of the severity of sickle cell anaemia. Trop Gastroenterol 2006;27(3):118-21.

[19] Yahaya IA. Biochemical features of hepatic dysfunction in Nigerians with sickle cell anaemia. Niger Postgrad Med J 2012;19(4):204-7.

[20] Ojuawo A, Adedoyin MA, Fagbule D. Hepatic function tests in children with sickle cell anaemia during vaso occlusive crisis. Cent Afr J Med 1994;40(12):342-5.

[21] Buchanan GR, Glader BE. Benign course of extreme hyperbilirubinemia in sickle cell anaemia: analysis of six cases. J Pediatr 1977;91(1):21-4.

[22] Ebert EC, Nagar M, Hagspiel KD. Gastrointestinal and hepatic complications of sickle cell disease. Clin Gastroenterol Hepatol 2010;8(6):483-9.

[23] Nouraie M, Cheng K, Niu X, et al. Predictors of osteoclast activity in patients with sickle cell disease. Haematologica 2011;96(8):1092-8.

[24] Afonja OA, Boyd AE. Plasma alkaline phosphatase and osteoblastic activity in sickle cell anaemia. J Trop Pediatr 1986;32(3):115-6.

[25] Adewoye AH, Chen TC, Ma Q, et al. Sickle cell bone disease: response to vitamin $\mathrm{D}$ and calcium. Am J Hematol 2008;83(4):271-4.

[26] Kotila T, Adedapo K, Adedapo A, et al. Liver dysfunction in steady state sickle cell disease. Ann Hepatol 2005;4(4):261-3.

[27] Isichei UP. Liver function and the diagnostic significance of biochemical changes in the blood of African children with sickle cell disease. J Clin Pathol 1980;33(7):626-30.

[28] Brody JI, Ryan WN, Haidar MA Serum alkaline phosphatase isoenzymes in sickle cell anaemia. JAMA 1975;232(7):738-41.

[29] Nath KA, Hebbel RP. Sickle cell anaemia: renal manifestations and mechanisms. Nat Rev Nephrol 2015;11(3):161-71.

[30] Marouf R, Mojiminiyi O, Abdella N, et al. Comparison of renal function markers in Kuwaiti patients with sickle cell disease. J Clin Pathol 2006;59(4):345-51.

[31] al-Naama LM, al-Sadoon EA, al-Sadoon TA. Levels of uric acid, urea and creatinine in Iraqi children with sickle cell disease. J Pak Med Assoc 2000;50(3):98-102. 